\title{
Oxide ceramics application to produce fixed prosthetic restorations
}

\section{Zastosowanie ceramiki tlenkowej w wykonawstwie stałych uzupełnień protetycznych}

\section{Joanna Gadomska, Anna Kochanek-Leśniewska}

Katedra Protetyki Stomatologicznej, Warszawski Uniwersytet Medyczny Department of Prosthetic Dentistry, Medical University of Warsaw Head: prof. dr hab. n. med. Jolanta Kostrzewa-Janicka

KEY WORDS:

oxide ceramics, ceramics based on zirconium dioxide, ceramics based on aluminium (III) oxide, fixed prosthetic restorations

\section{Summary}

The mechanical strength of glass ceramics based on leucite and lithium disilicate, insufficient to replace extensive tooth gaps, their high brittleness and susceptibility to cracking, and thus limited clinical use, are arguments for making zirconium dioxide widely used in dentistry. Permanent restorations based on zirconium dioxide are currently an alternative to metalceramic structures, both in the reconstruction of qualitative and quantitative single tooth defects, and in the design of extensive, multi-segmented restorations based on natural teeth or bone implants. The high parameters of the mechanical strength of zirconium oxide prosthetic structures have been achieved by completely eliminating the glass component from the material structure. The group of oxide ceramics also includes ceramics based on aluminium (III) oxide, which is rarely used today.

The aim of the study is to present and characterize the types of oxide ceramics taking into account the indications, possibilities and limitations of their clinical application, processing technology and the advantages and disadvantages of each types of oxide ceramics
HASŁA INDEKSOWE:

ceramika tlenkowa, ceramika na bazie dwutlenku cyrkonu, ceramika na bazie tlenku glinu (III), stałe uzupełnienia protetyczne

Streszczenie
Wytrzymałośc mechaniczna ceramik szklanych
na bazie leucytu oraz dwukrzemianu litu, niewy-
starczająca do uzupetniania rozlegtych braków
zębowych, ich duża kruchość i podatność na pęka-
nie pod wptywem dużych sit zgryzowych wyzwa-
lanych wrejonie zębów trzonowych, a tym samym
ograniczone zastosowanie kliniczne sprawity, iż
szerokie zastosowanie w stomatologii zyskat dwu-
tlenek cyrkonu. Uzupetnienia state na podbudo-
wie z dwutlenku cyrkonu stanowia obecnie alter-
natywe dla konstrukcji metalowo-ceramicznych
zarówno w odtwarzaniu braków jakościowych
i ilościowych pojedynczych zębów, jak również
w projektowaniu rozlegtych, wieloczłonowych
rekonstrukcji opartych na zębach własnych badź
wszczepach śródkostnych. Wysokie parametry
wytrzymałości mechanicznej konstrukcji prote-
tycznych z dwutlenku cyrkonu osiagnięto poprzez
całkowite wyeliminowanie komponenty szklanej
ze struktury materiatu. Do grupy ceramik tlen-
kowych zaliczana jest również ceramika na bazie
tlenku glinu (III), obecnie rzadko stosowana.
Celem niniejszej pracy jest przedstawienie
oraz charakterystyka poszczególnych rodzajów
ceramik tlenkowych z uwzględnieniem wskazań,


in the manufacture of all-ceramic permanent restorations.

\section{Introduction}

Considering the conditions of the oral cavity, oxide ceramics are characterized by high mechanical strength. The crystalline structure of the material, completely devoid of the glass phase, enables the reconstruction of extensive edentulous spaces with the use of permanent prosthetic constructions with high mechanical strength and satisfactory aesthetics. Among the oxide ceramics, the following are distinguished: ceramics based on zirconium dioxide and ceramics based on aluminum (III) oxide.

\section{Ceramics based on zirconium dioxide}

Zirconium dioxide ceramics belongs to the group of structural ceramics, it is a singlephase material composed of pure crystals and it is completely devoid of the glass phase. ${ }^{1-3}$ Zirconium dioxide shows polymorphism and occurs in three crystallographic forms: at room temperature it takes the monoclinic (cubic) form, while with increasing temperature it is transformed through the tetragonal form to the regular (monocyclic) form. The conversion of monoclinic to tetragonal form is accompanied by an approximately $5 \%$ decrease in the volume of the material. Due to the best biomechanical properties, the metastable tetragonal form is most preferred. The addition of stabilizing oxides such as yttrium oxide, cerium oxide, calcium oxide and magnesium oxide enable storage at room temperature. Among the dental ceramics based on zirconium dioxide currently available on the market, the most widely used is możliwości i ograniczeń ich zastosowania klinicznego, technologii przetwarzania a także zalet $i$ wad danych rodzajów ceramik konstrukcyjnych $w$ wykonawstwie statych uzupetnien całoceramicznych.

\section{Wstęp}

Ceramika tlenkowa charakteryzuje się wysoką wytrzymałością mechaniczną w warunkach jamy ustnej. Krystaliczna struktura materiału, w całości pozbawionego fazy szklanej, pozwala na odtwarzanie rozległych braków zębowych z zastosowaniem stałych konstrukcji protetycznych o dużej wytrzymałości mechanicznej i zadowalającej estetyce. Wśród ceramik tlenkowych wyróżniane są: ceramika na bazie dwutlenku cyrkonu oraz ceramika na bazie tlenku glinu (III).

\section{Ceramika na bazie dwutlenku cyrkonu}

Ceramika na bazie dwutlenku cyrkonu należy do grupy ceramik konstrukcyjnych, jest materiałem jednofazowym złożonym $\mathrm{z}$ czystych kryształów, całkowicie pozbawionym fazy szklanej. ${ }^{1-3}$ Dwutlenek cyrkonu wykazuje polimorfizm i występuje w trzech odmianach krystalograficznych: w temperaturze pokojowej przyjmuje postać jednoskośną (kubiczną), natomiast wraz ze wzrostem temperatury ulega przekształceniu poprzez odmianę tetragonalną do regularnej (monocyklicznej). Przemianie formy jednoskośnej $\mathrm{w}$ tetragonalną towarzyszy około 5\% spadek objętości materiału. Ze względu na najlepsze właściwości biomechaniczne najbardziej korzystną jest metastabilna postać tetragonalna. Dodatek tlenków stabilizujących, takich jak tlenek itru, tlenek ceru, tlenek wapnia oraz tlenek magnezu pozwala na jej utrzymanie $\mathrm{w}$ temperaturze pokojowej. Spośród dostępnych obecnie na rynku ceramik dentystycznych na bazie dwutlenku 
Y-TZP (Yttrium-Stabilized Tetragonal Zirconia Policrystals). This material consists of $97 \%$ of fine crystals, homogeneous in terms of shape and size $(0.2-1 \mu \mathrm{m})$, of the tetragonal form of zirconium dioxide stabilized with yttrium oxide in the amount of about 3\% by weight. Currently, zirconia ceramics with a content of $4 \mathrm{~mol} \%$ and $5 \mathrm{~mol} \%$ of yttrium oxide are also frequently preferred. Increasing the content of the stabilizer is one of the factors favourably influencing the aesthetics of restorations. 1,3-6

The very high mechanical strength of ceramics based on zirconium dioxide is related to, inter alia, the phenomenon of phase transformation, also referred to as "enhancing transformation" or "stress-induced transformation." External loads can propagate cracks in the zirconium dioxide structure. They stimulate the transformation of the tetragonal form into a monoclinic one in the fracture area. This process occurs with a simultaneous increase in the volume of grains within the range of $3-5 \%$.

Compressive stresses released in the area of the crack tip limit its further propagation and the crack is closed. A necessary prerequisite for the enhancement transformation is the correct zirconium dioxide crystal size of about $0.5 \mu \mathrm{m}$. Its reduction below the critical value of 0.3 $\mu \mathrm{m}$ makes the transformation of the tetragonal form into a monoclinic one impossible. ${ }^{1-3,7,8}$ This particular mechanism, characteristic of zirconium dioxide only, significantly increases the $\mathrm{K}_{\mathrm{IC}}$ stress intensity factor. This material is characterized by the highest parameters of mechanical strength among all known, and currently used in dentistry, ceramic materials. Hardness of $13 \mathrm{GPa}$ on the Vickers scale of full-contour zirconium dioxide, bending strength of 1200-1400 MPa, and tensile strength of $7-10 \mathrm{MPa}$ enable the design of extensive multi-unit permanent prosthetic constructions throughout the entire dental arch span. Zirconium ceramics ensure the longterm durability of ceramic bridges as they can cyrkonu najszersze zastosowanie znalazł Y-TZP (ang. Yttrium Stabilized Tetragonal Zirconia Policrystals). Materiał ten w 97\% złożony jest z drobnych, jednorodnych pod względem kształtu i wielkości $(0,2-1 \mu \mathrm{m})$ kryształów tetragonalnej formy dwutlenku cyrkonu stabilizowanej tlenkiem itru w ilości około 3\% objętości wagowej. Obecnie często stosowana jest również ceramika cyrkonowa o zawartości $4 \mathrm{~mol} \%$ oraz $5 \mathrm{~mol} \%$ tlenku itru. Zwiększenie udziału stabilizatora jest jednym z czynników korzystnie wpływających na estetykę uzupełnień. 1,3-6 Bardzo wysoka wytrzymałość mechaniczna ceramiki na bazie dwutlenku cyrkonu związana jest między innymi ze zjawiskiem przemiany fazowej określanej również jako „transformacja wzmacniająca” lub „transformacja indukowana naprężeniem." Zewnętrzne obciążenia mogą skutkować rozprzestrzenianiem się pęknięć w strukturze dwutlenku cyrkonu. Stanowią one bodziec do przemiany formy tetragonalnej w jednoskośną w rejonie pęknięcia. Proces ten następuje $\mathrm{z}$ jednoczesnym wzrostem objętości ziaren w granicach 3 - 5\%. Naprężenia ściskające wyzwolone w rejonie wierzchołka pęknięcia ograniczają jego dalszą propagację i dochodzi do zamknięcia szczeliny. Niezbędnym warunkiem, aby mogła nastąpić transformacja wzmacniająca jest właściwy rozmiar kryształów dwutlenku cyrkonu wynoszący około $0,5 \mu \mathrm{m}$. Jego zmniejszenie poniżej krytycznej wartości $0,3 \mu \mathrm{m}$ uniemożliwia przemianę formy tetragonalnej $\mathrm{w}$ jednoskośną. ${ }^{1-3,7,8}$ Ten szczególny mechanizm, charakterystyczny jedynie dla dwutlenku cyrkonu, wpływa znacząco na zwiększenie współczynnika intensywności naprężeń $\mathrm{K}_{\mathrm{IC}}$. Materiał ten charakteryzuje się najwyższymi parametrami wytrzymałości mechanicznej spośród wszystkich znanych i stosowanych obecnie w stomatologii tworzyw ceramicznych. Twardość pełnokonturowego dwutlenku cyrkonu wynosząca 13 GPa w skali Vickersa, wytrzymałość na zginanie 1200-1400 MPa oraz odporność na 
withstand occlusal loads of up to 2,500 N, more than twice the amount of forces generated in the region of molar teeth $(500-850 \mathrm{~N}))^{1,3,9}$

Zirconium ceramics, completely devoid of the glass phase, cannot be etched with hydrofluoric acid, which makes the formation of an adhesive bond between the prosthetic restoration and the cement impossible. Traditional types of cements - phosphate, carboxylic, or glass ionomer - are used for fixing zirconium dioxide restorations. Composite materials, which have a dual mechanism of bonding, can also be used. Conventional cementation presents a lower risk of making a mistake compared to adhesive cementation due to the less complicated procedure; however, in order to obtain a sufficiently strong mechanical bond between the restoration and the abutment, less radical preparation is required to ensure adequate retention. 1,2,10,11

Despite satisfactory technical parameters, the use of zirconium oxide is also burdened with certain limitations. Under unfavourable oral conditions, zirconium restorations are subject to wear, known as low-temperature aging. The potential causes of material degradation include improper chemical composition and errors at the manufacturing stage. In the presence of water, the metastable tetragonal form is slowly transformed into the stable monocyclic form. This process begins at the surface of the restoration and gradually spreads inwards. An increase in the monoclinic phase content increases the risk of microcracks appearing in the structure of the material, which may result in subsequent fracture of the restoration. , $^{7}$

The high content of crystals in the structure of zirconium ceramics is responsible for its high refractive index. The unsatisfactory aesthetic effect poses a certain limitation in the reconstruction of anterior teeth with the use of highly opaque crowns and zirconium bridges. However, the low translucency of full-contour zirconium dioxide restorations is desirable rozciąganie rzędu 7-10 MPa umożliwiają projektowanie rozległych wieloczłonowych stałych konstrukcji protetycznych w obrębie całego łuku zębowego. Ceramika cyrkonowa zapewnia długoterminowe przetrwanie mostów ceramicznych, gdyż wytrzymuje obciążenia okluzyjne do $2500 \mathrm{~N}$, ponad dwukrotnie przewyższając wielkości sił wyzwalanych w rejonie zębów trzonowych (500-850 N). 1,3,9

Ceramika cyrkonowa, całkowicie pozbawiona fazy szklanej, nie poddaje się wytrawianiu kwasem fluorowodorowym, co uniemożliwia wytworzenie adhezyjnego połączenia pomiędzy uzupełnieniem protetycznym a cementem. Do osadzania uzupełnień $\mathrm{z}$ dwutlenku cyrkonu dedykowane są cementy tradycyjne - fosforanowy, karboksylowy lub glassjonomerowy. Można również stosować kompozytowe materiały dualne. Cementowanie konwencjonalne stwarza mniejsze ryzyko popełnienia błędu w stosunku do cementowania adhezyjnego ze względu na mniej skomplikowaną procedurę postępowania, jednak w celu uzyskania wystarczająco silnego połączenia mechanicznego pomiędzy uzupełnieniem a filarem wymagana jest mniej radykalna preparacja w celu zapewnienia odpowiedniej retencji konstrukcji protetycznej. $1,2,10,11$

Pomimo zadowalających parametrów technicznych, zastosowanie tlenku cyrkonu napotyka również na pewne ograniczenia. W niesprzyjających warunkach jamy ustnej uzupełnienia cyrkonowe podlegają zużyciu, które określane jest mianem starzenia niskotemperaturowego. Wśród potencjalnych przyczyn degradacji materiału wymieniane są niewłaściwy skład chemiczny oraz błędy na etapie wytwarzania. W obecności wody metastabilna postać tetragonalna podlega powolnej transformacji w stabilną postać monocykliczną. Proces ten rozpoczyna się na powierzchni uzupełnienia i stopniowo rozprzestrzenia się w głąb. Wzrost zawartości fazy jednoskośnej zwiększa ryzyko powstawania mikropęknięć w strukturze 
in the case of reconstruction of discoloured abutments reinforced with metal posts or in a situation where the patient's teeth have been bleached. $1,8,12$

In order to improve the insufficient aesthetics of opaque full-contour restorations made of zirconium oxide, and to protect the opposing teeth against excessive abrasion, the zirconium substructure is commonly veneered with feldspar porcelain. This technique requires a more radical preparation of the abutment. Moreover, at the stage of treatment planning, it should be taken into account that the resistance to damage of this type of structure is determined by the presence of facing porcelain, whose mechanical strength is only about 100 $150 \mathrm{MPa}$. Therefore, one of the most frequently observed complications related to the use of veneered zirconium ceramics is the chipping of the porcelain layer under the influence of high occlusal forces released in the lateral segments of the dental arch. ${ }^{6,8,13-16}$

Zirconium oxide can only be processed with digitally controlled milling technology. It is produced in two forms, each of which is dedicated to a different milling method. The soft and easy-to-process blocks or discs made of pre-sintered zirconium dioxide, used in the green body technique, are subjected to a multistage sintering process at the temperature of $1600-1700^{\circ} \mathrm{C}$ after milling, during which the intercrystalline spaces are compressed. This way the material gains considerable mechanical strength and the finished form of prosthetic restoration is reduced by approximately $20 \%$ to the computer-programmed desired size. On the other hand, in the HIP (hot isostatic pressing) technique, the construction is milled in the target dimension from hard blocks of sintered ceramics. The advantage of this method is the shortening of the laboratory stage, but cutting the finished ceramics may deteriorate its strength parameters. ${ }^{1,3,17}$

One of the most widely used processing tworzywa, co może skutkować złamaniem uzupełnienia. ${ }^{7,8}$

Duża zawartość kryształów w strukturze ceramiki cyrkonowej sprawia, iż charakteryzuje się ona wysokim współczynnikiem refrakcji. Niezadowalający efekt estetyczny stanowi pewne ograniczenie w rekonstrukcji zębów przednich z zastosowaniem wysoce opakerowych koron i mostów cyrkonowych. Jednak niska przezierność uzupełnień z pełnokonturowego dwutlenku cyrkonu pożądana jest w przypadku odbudowy filarów przebarwionych, zaopatrzonych w metalowe wkłady koronowo-korzeniowe lub w sytuacji, gdy zęby pacjenta poddawane były wybielaniu. ${ }^{1,8,12}$

W celu poprawy niedostatecznej estetyki nieprzeziernych uzupełnień pełnokonturowych z tlenku cyrkonu oraz ochrony zębów przeciwstawnych przed nadmiernym starciem, powszechnie stosowana jest technika licowania podbudowy cyrkonowej porcelaną skaleniową. Technika ta wymaga bardziej radykalnej preparacji filaru. Ponadto na etapie planowania leczenia należy uwzględnić fakt, iż odporność na uszkodzenia tego typu konstrukcji determinowana jest obecnością porcelany licującej, której wytrzymałość mechaniczna wynosi zaledwie około 100-150 MPa. Dlatego jednym z najczęściej obserwowanych powikłań związanych z użytkowaniem konstrukcji z licowanej ceramiki cyrkonowej jest odpryskiwanie warstwy porcelany (chipping) pod wpływem dużych sił zgryzowych wyzwalanych w bocznych odcinkach łuku zębowego. 6,8,13-16

Tlenek cyrkonu może być przetwarzany jedynie $\mathrm{w}$ technologii frezowania sterowanego cyfrowo. Produkowany jest w dwóch postaciach, z których każda dedykowana jest do innej metody frezowania. Stosowane w technice green bo$d y$ miękkie i łatwe do obróbki bloczki lub krążki z presynteryzowanego dwutlenku cyrkonu po zakończeniu frezowania poddawane są procesowi wielostopniowego spiekania w temperaturze $1600-1700{ }^{\circ} \mathrm{C}$, podczas którego następuje 
systems for zirconium dioxide ceramics today is IPS E-max ZirCAD (Ivoclar Vivadent, Lichtenstein). The zirconium ceramics, packaged in the form of discs or blocks, are available in three levels of translucency: MO - medium opaque, LT - low transparent, and MT - medium transparent, as well as in the MT Multi system with different transparency. Depending on the crystal structure and the amount of the stabilizer (yttrium oxide), IPS E-max ZirCAD prefabricates can be divided into two groups. The first one includes IPS E-max ZirCAD MO and LT, containing only crystals of the tetragonal form of zirconium dioxide, stabilized with yttrium oxide in the amount of about $4.5-6 \%-3 \mathrm{Y}-\mathrm{TZP}$. The mechanical strength of up to $1150 \mathrm{MPa}(\mathrm{MO})$ and 1200 $\mathrm{MPa}$ (LT) enables the fabrication of thin-walled restorations $(0.4 \mathrm{~mm}$ - in the anterior segment of the dental arch, and $0.6 \mathrm{~mm}$ - in the posterior one) and the range of indications for their use includes crown substructures and multi-unit bridges (MO), and also full-contour single and multi-unit structures for LT. The second group of IPS E-max ZirCAD products consists of IPS E-max ZirCAD MT Multi and IPS E-max ZirCAD MT. The increase in transparency of these materials was achieved by increasing the content of yttrium oxide to about $6.5-8.0 \%$ (4Y-TZP), increasing the size of zirconium oxide crystals $(0.65 \mu \mathrm{m})$ and the monoclinic phase to about $25 \%$ by volume. These materials are used to make restorations using the cutback method, in which feldspar porcelain is fired in the area of the incisal edges and cusp tips. ZirCAD MT Multi additionally contains 5Y-TZP, in which the amount of yttrium oxide has been increased to about $9.0-10.0 \%$, and the cubic form of zirconium oxide crystals reaches up to $50 \%$, which ensures satisfactory aesthetics of zirconium restorations without the need of firing porcelain or the application of microstructure technique. IPS E-max ZirCAD with increased translucency is used for the kompresja przestrzeni międzykrystalicznych materiał zyskuje znaczną wytrzymałość mechaniczną, a powstała forma uzupełnienia protetycznego ulega zmniejszeniu o około $20 \%$ do zaprogramowanej komputerowo, żądanej wielkości. Natomiast w technice HIP (hot isostatic pressing) konstrukcja jest frezowana w docelowym wymiarze z twardych bloczków spieczonej ceramiki. Zaletą tej metody jest skrócenie etapu laboratoryjnego, jednak skrawanie gotowej ceramiki może pogarszać jej parametry wytrzymałościowe. ${ }^{1,3,17}$

Obecnie jednym z najpowszechniej stosowanych systemów przetwarzania ceramiki na bazie dwutlenku cyrkonu jest IPS E-max ZirCAD (Ivoclar Vivadent, Lichtenstein). Konfekcjonowana w postaci dysków lub bloczków ceramika cyrkonowa dostępna jest w trzech poziomach przezierności: MO - średnio opakerowa, LT - nisko transparentna oraz MT - średnio transparentna, a także w systemie MT Multi o zróżnicowanej przezierności. W zależności od struktury krystalicznej oraz ilości zawartego stabilizatora - tlenku itru, prefabrykaty IPS E-max ZirCAD można podzielić na dwie grupy. Do pierwszej z nich zaliczane są IPS E-max ZirCAD MO i LT, zawierające jedynie kryształy tetragonalnej formy dwutlenku cyrkonu, stabilizowanej tlenkiem itru w ilości około 4,5-6\% -3Y-TZP. Wytrzymałość mechaniczna sięgająca $1150 \mathrm{MPa}(\mathrm{MO})$ oraz $1200 \mathrm{MPa}$ (LT) pozwalają na wykonywanie cienkościennych uzupełnień ( $0,4 \mathrm{~mm}$ - w odcinku przednim łuku zębowego oraz $0,6 \mathrm{~mm}-$ w odcinku bocznym), zaś zakres wskazań do stosowania obejmuje podbudowy koron oraz wieloczłonowych mostów (MO), a dla LT również pełnokonturowe konstrukcje jedno- i wielopunktowe. Drugą grupę produktów IPS E-max ZirCAD tworzą IPS E-max ZirCAD MT Multi oraz IPS E-max ZirCAD MT. Wzrost transparencji tych materiałów uzyskano dzięki zwiększeniu zawartości tlenku itru do około 6,5-8,0\% (4Y-TZP), zwiększeniu rozmiaru kryształów tlenku cyrkonu $(0,65 \mu \mathrm{m})$ oraz 
production of full-contour crowns, adhesive bridges and up to three-unit bridges with a wall thickness of $0.8 \mathrm{~mm}$ - in the anterior segment, and $1.0 \mathrm{~mm}$ - in the molar teeth region, because the limited amount of tetragonal phase in favour of monoclinic phase reduces the mechanical strength to about $850 \mathrm{MPa}$.

One of the most recent products currently available on the market is IPS E-max ZirCAD Prime (Ivoclar Vivadent, Lichtenstein). Fullcontour restorations are cut from a layered block using Gradient Technology (GT). Setting the design of the restoration in a computer program in the appropriate area of the zirconium block allows obtaining a construction with the desired mechanical strength. Moreover, the possibility of freely manoeuvring the mutual proportions of the dentine (3Y-TZP), transition, and incisal (5Y-TZP) layers allows achieving a satisfactory aesthetic effect and faithful recreation of the individual features of the patient's natural dentition. The maximum bending strength of the material in the dentine layer is $1200 \mathrm{MPa}$, and with increasing translucency in the incisal area, it decreases to about $650 \mathrm{MPa}$, which is dictated by the different crystal structures of each layers. IPS E-max ZirCAD Prime is available in 16 colours from the $\mathrm{A}$ - $\mathrm{D}$ range and in 4 BL colours. According to the manufacturer's recommendations, the scope of indications for the use of the material includes both single crowns and extensive, even 14-unit bridges, because the high flexural strength does not actually limit the extent of the prosthetic construction.

\section{Ceramics based on aluminum (III) oxide}

Aluminium trioxide in prosthetic materials science was initially used to increase the mechanical strength of glass ceramics. The method of infiltrating dental porcelain with aluminium trioxide crystals, developed in 1965 by McLean and Hughes, resulted in achieving a bending strength of $180 \mathrm{MPa}$, which is a twofold increase compared to feldspar ceramics. ${ }^{16}$ The udziału fazy jednoskośnej do około 25\% objętości. Materiały te wykorzystywane są do wykonywania uzupełnień metodą cut-back, w której na podbudowę w okolicach brzegów siecznych i szczytów guzków napalana jest porcelana skaleniowa. ZirCAD MT Multi zawiera dodatkowo 5Y-TZP, w którym ilość tlenku itru została zwiększona do około 9,0-10,0\%, zaś kubiczna postać kryształów tlenku cyrkonu osiąga nawet $50 \%$, co zapewnia zadowalającą estetykę uzupełnień cyrkonowych bez konieczności napalania porcelany lub z zastosowaniem $\mathrm{w}$ technice mikrostruktury. IPS E-max ZirCAD o zwiększonej przezierności wykorzystywane są do produkcji pełnokonturowych koron, mostów adhezyjnych i maksymalnie trzyczłonowych mostów o ścianach grubości $0,8 \mathrm{~mm}$ - w odcinku przednim oraz 1,0 mm-w rejonie zębów trzonowych, gdyż ograniczony udział fazy tetragonalnej na rzecz fazy jednoskośnej zmniejsza wytrzymałość mechaniczną do około $850 \mathrm{MPa}$.

Jednym z najnowszych, spośród dostępnych obecnie na rynku produktów jest IPS E-max ZirCAD Prime (Ivoclar Vivadent, Lichtenstein). Pełnokonturowe uzupełnienia wycinane są z bloku warstwowego w Technologii Gradacji (Gradient Technology - GT). Ustawienie projektu uzupełnienia $\mathrm{w}$ programie komputerowym w odpowiednim obszarze bloku cyrkonowego umożliwia uzyskanie konstrukcji o pożądanej wytrzymałości mechanicznej. Ponadto możliwość dowolnego manewrowania wzajemnymi proporcjami warstw: dentynowej (3Y-TZP), przejściowej oraz warstwy brzegu siecznego (5Y-TZP) pozwala osiągnąć zadowalający efekt estetyczny i wiernie odtworzyć indywidualne cechy naturalnego uzębienia pacjenta. Maksymalną wytrzymałość na zginanie materiał osiąga $\mathrm{w}$ warstwie zębinowej $1200 \mathrm{MPa}$, zaś wraz ze wzrostem przezierności w rejonie brzegu siecznego maleje ona do około $650 \mathrm{MPa}$, co podyktowane jest odmienną strukturą krystaliczną poszczególnych warstw. IPS E-max ZirCAD Prime dostępny jest w 16 
dynamic development of dental materials science enabled the construction of crowns and 3-4 unit bridges in the anterior segment of the dental arch made of aluminium ceramics in the In-Ceram Alumina system (Vita Zanfabrik, Germany). The 1-5 $\mu \mathrm{m}$ aluminium oxide crystals, evenly distributed in the calciumlanthanum glass matrix, ensure the bridging reinforcement mechanism typical of this type of two-phase ceramics. The limited propagation of cracks in the material structure ensures high fracture strength of prosthetic constructions (930-1168 N). The hardness on the Vickers scale is $11.5 \mathrm{GPa}$ and the flexural strength is 350-594 MPa. ${ }^{2,17-22}$

The Procera All-Ceram system, used for the first time in the $90 \mathrm{~s}$, made it possible to process $99.9 \%$ of monophasic ceramics composed of aluminium oxide (III) crystals in the CAD / CAM technology. The sintering process at the temperature of $1600-1700^{\circ} \mathrm{C}$ of the milled aluminium trioxide substructure causes shrinkage and a reduction of its volume by about $20 \%$, which increases its mechanical strength by reducing the intercrystalline spaces between the grains of aluminium trioxide. ${ }^{2}$

The pure aluminium oxide sinter used in the Procera All Ceram system is made of corundum grains with an average size of $4 \mu \mathrm{m}$. The complete elimination of the glass phase from the material structure ensures the high mechanical strength of permanent restorations. Homogeneous sinter of aluminium trioxide is characterized by the highest hardness among all types of dental ceramics - $15 \mathrm{GPa}$ on the Vickers scale, fracture resistance is 901$1158 \mathrm{~N}$, while the bending strength is over eight times higher than that of feldspar porcelain, reaching the values of 601-687 MPa. The range of clinical indications for the use of aluminium ceramics includes crown substructures in the anterior and posterior segments of the dental arch, bridges, and implant-supported crowns. ${ }^{16,22-24}$ kolorach z gamy A - D oraz w 4 kolorach BL. Zgodnie z zaleceniami producenta zakres wskazań do stosowania materiału obejmuje zarówno pojedyncze korony, jak również rozległe, nawet 14-punktowe mosty, gdyż wysoka wytrzymałość na zginanie właściwie nie stwarza ograniczeń dotyczących rozległości wykonywanej konstrukcji protetycznej. ${ }^{7}$

\section{Ceramika na bazie tlenku glinu (III)}

Trójtlenek glinu w materiałoznawstwie protetycznym początkowo wykorzystywano w celu zwiększenia wytrzymałości mechanicznej ceramik szklanych. Opracowana w 1965 r. przez McLean'a i Hughes'a metoda infiltracji porcelany dentystycznej kryształami trójtlenku aluminium spowodowała uzyskanie wytrzymałości na zginanie rzędu $180 \mathrm{MPa}$, co oznacza dwukrotny wzrost $\mathrm{w}$ stosunku do ceramiki skaleniowej. ${ }^{16}$ Dynamiczny rozwój materiałoznawstwa stomatologicznego pozwolił na wykonywanie podbudowy koron i 3-4 członowych mostów w przednim odcinku łuku zębowego $\mathrm{z}$ ceramiki glinowej $\mathrm{w}$ systemie InCeram Alumina (Vita Zanfabrik, Germany). Równomiernie rozmieszczone w matrycy ze szkła wapniowo-lantanowego kryształy tlenku glinu (III) o wielkości 1-5 $\mu \mathrm{m}$ zapewniają charakterystyczny dla tego typu ceramiki dwufazowej mechanizm wzmocnienia w efekcie mostkowania. Ograniczona propagacja pęknięć w strukturze materiału zapewnia wysoką wytrzymałość konstrukcji protetycznych na złamanie (930-1168 N). Twardość w skali Vickersa wynosi 11,5 GPa, zaś wytrzymałość na zginanie osiagga 350-594 MPa. 2,17-22

Zastosowany po raz pierwszy w latach 90-tych system Procera All-Ceram pozwolił na przetwarzanie ceramiki monofazowej w 99,9\% złożonej z kryształów tlenku glinu (III) w technologii CAD/CAM. Proces spiekania w temperaturze $1600-1700^{\circ} \mathrm{C}$ wyfrezowanej podbudowy z trójtlenku aluminium powoduje skurcz i zmniejszenie objętości konstrukcji o około 


\section{Conclusion}

The high mechanical strength of the oxide ceramics based on zirconium oxide and, less popular, aluminium ceramics, enables prosthetic rehabilitation of both patients with extensive tooth deficiencies and edentate patients with the use of permanent all-ceramic restorations based on own teeth and/or implants. The possibility of eliminating removable dentures which involve the mucosal transmission of forces to the foundation area and the use of permanent structures supported on the periodontium allows recreating the conditions as close as possible to those provided by natural dentition. Moreover, the complete biocompatibility of ceramic materials and the satisfactory aesthetics of the restorations facilitate the maintenance of the good condition of the marginal periodontium and faithful imitation of the anatomy of the hard tissues of natural teeth.
$20 \%$, co skutkuje zwiększeniem jego wytrzymałości mechanicznej w wyniku zmniejszenia przestrzeni międzykrystalicznych pomiędzy ziarnami korundu. ${ }^{2}$

Spiek czystego tlenek glinu (III) stosowany w systemie Procera All Ceram zbudowany jest z ziaren korundu o średniej wielkości $4 \mu \mathrm{m}$. Całkowite wyeliminowanie fazy szklanej ze struktury materiału zapewnia wysoką wytrzymałość mechaniczną uzupełnień stałych. Homogenny spiek trójtlenku aluminium charakteryzuje się najwyższą spośród wszystkich rodzajów ceramik dentystycznych twardością 15 GPa w skali Vickersa, odporność na złamanie wynosi 901-1158 N, natomiast wytrzymałość na zginanie ponad ośmiokrotnie przewyższa wytrzymałość porcelany skaleniowej, osiągając wartości 601-687 MPa. Zakres wskazań klinicznych do stosowania ceramiki glinowej obejmuje podbudowy koron w odcinku przednim i bocznym, mosty a także korony oparte na implantach. ${ }^{16,22-24}$

\section{Podsumowanie}

Duża wytrzymałość mechaniczna ceramiki tlenkowej na bazie tlenku cyrkonu oraz, obecnie rzadziej stosowanej, ceramiki glinowej stwarza możliwość rehabilitacji protetycznej pacjentów z rozległymi brakami zębowymi, a także osób bezzębnych z zastosowaniem uzupełnień stałych pełnoceramicznych opartych na zębach własnych oraz na wszczepach śródkostnych. Możliwość wyeliminowania protez ruchomych o śluzówkowym przenoszeniu sił na podłoże i zastosowanie konstrukcji stałych podpartych ozębnowo pozwala na odtworzenie warunków możliwie najbardziej zbliżonych do tych, jakie zapewnia uzębienie naturalne. Ponadto całkowita biozgodność materiałów ceramicznych oraz zadowalająca estetyka uzupełnień ułatwiają zachowanie dobrego stanu przyzębia brzeżnego i wiernie odtwarzają anatomię tkanek twardych zębów naturalnych. 


\section{References / Piśmiennictwo}

1. Szczyrek P, Mierzwińska-Nastalska E: Uzupełnienia ceramiczne. Postępowanie kliniczne i wykonawstwo laboratoryjne. Med Tour Press International, Otwock 2011.

2. Okoński P, Lasek K, Mierzwińska-Nastalska $E$ : Kliniczne zastosowanie wybranych materiałów ceramicznych. Protet Stomatol 2012; LXII, 181-189.

3. Bunek $S$ : Ceramics \& Surface Treatments. Dental Advisor 2018; 35: 3.

4. Majewski S, Pryliński M: Materiały i technologie współczesnej protetyki stomatologicznej. Wydawnictwo Czelej, Lublin 2013.

5. Wydra M, Grelowska I: Materiały ceramiczne w stomatologii. Szkło i ceramika 2017; 6 .

6. Nistor L, Gradinaru M, Rica R, Marasescu P, Stan M, Manolea H, Augustin I, Moraru I: Zirconia Use in Dentistry - Manufacturing and Properties. Current Health Sciences Journal 2019; 45(1): 28-35.

7. Hämmerle Ch, Sailer I, Thoma A, Hölg G, Suter A, Ramel Ch: Ceramika dentystyczna. Wskazania dla praktyki (Dentale Keramiken. Aktuelle Schwerpunkte fur die Klinik). Quintessenz Verlags-GmbH, Berlin 2008.

8. Agustin-Panadero R, Serra-Pastor B, RoigVanaclocha A, Fons-Font A, Sola-Ruiz MF: Fracture resistance and the mode of failure produced in metal-free crowns cemented onto zirconia abutments in dental implants. PLoS ONE 2019; 14(8): e0220551.

9. Dejak B: Kompendium wykonywania uzupełnień protetycznych. Med Tour Press International, Warszawa 2014.

10. Majewski S: Rekonstrukcja zębów uzupełnieniami stałymi. Wydawnictwo Fundacji Rozwoju Protetyki, Kraków 2005.

11. Zhang Y, Kelly JR: Dental ceramics for restoration and metal-veneering. Dent Clin North Am. 2017; 61(4): 797-819.

12. Hamza TA, Sherif RM: Fracture Resistance of Monolithic Glass-Ceramics Versus Bilayered
Zirconia-Based Restorations. J Prosthodont 2019; 28: 259-264.

13. Ferruzzi F, Ferrairo BM, Piras FF, Borges AF, Rubo JH: Fatigue survival and damage modes of lithium disilicate and resin nanoceramic crowns. J Appl Oral Sci 2019; 27: e20180297.

14. Güngör MB, Nemli SK, Yilmaz H, Aydin $C$ : Fracture resistance of different implant supported ceramic abutment/crown systems. Eur Oral Res 2019; 53(2): 80-87.

15. Alessandretti R, Ribeiro R, Borba M, Della Bona A: Fracture Load and Failure Mode of CAD-on Ceramic Structures. Brazil Dent J 2019; 30(4): 380-384.

16. Dejak B, Kacprzak M, Suliborski B, Śmielak $B$ : Struktura i niektóre właściwości ceramik dentystycznych stosowanych $\mathrm{w}$ uzupełnieniach pełnoceramicznych $\mathrm{w}$ świetle literatury. Protet Stomatol 2006; LVI, 6: 471-477.

17. McLean JW: Evolution of dental ceramics in the twentieth century. J Prosthet Dent 2001; 85(1): 61-66.

18. Quinn JB, Sundar V, Lioyd IK: Influence of microstructure and chemistry on fracture toughness of dental ceramics. Dent Mat 2003; 19: 603-611.

19. Niezgoda T, Małachowski J, Szymczyk W: Modelowanie numeryczne mikrostruktury ceramiki. Wydawnictwa Naukowo-Techniczne, Warszawa 2005.

20. Raigrodski AJ: Contemporary materials and technologies for all-ceramic fixed partial dentures: a review of the literature. J Prosthet Dent 2004; 92(6): 557-562.

21. Guazzato M, Albakry M, Swainn M, Ironside J: Mechanical properties of In-Ceram Alumina and In-Ceram Zirconia. Int $\mathrm{J}$ Prosthodont 2002; 15(4): 339-346.

22. Tinschert $J$, Natt $G$, Mautsch $W$, Augthun $M$, Spiekermann $H$ : Fracture resistance of lithium disilicate-, alumina-, and zirconiabased three-unit fixed partial dentures: a 
laboratory study. Int J Prosthodont 2001; 14(3): 231-238.

23. Pallis K, Griggs JA, Woody RD, Guillen GE, Miller $A W$ : Fracture resistance of three allceramic restorative systems for posterior applications. J Prosthet Dent 2004; 91(6): 561-569.
24. Ottl P, Piwowarczyk A, Lauer HC, Hegenbarth EA: The Procera AllCeram system. Int $\mathrm{J}$ Periodont Restor Dent 2000; 20: 151-161.

Zaakceptowano do druku: 3.08.2021 r.

Adres autorów: 02-097 Warszawa, ul. Binieckiego 6.

(c) Zarząd Główny PTS 2021. 